\title{
Phosphoproteins Involved in the Signal Transduction of Cryptogein, an Elicitor of Defense Reactions in Tobacco
}

\author{
Fatma Lecourieux-Ouaked, Alain Pugin, and Angela Lebrun-Garcia \\ UMR INRA/Université de Bourgogne, Laboratoire de Biochimie, Biologie Cellulaire et Ecologie des Interac- \\ tions Plantes/Micro-organismes, 17 rue Sully, BV 1540, Dijon Cedex, 21034, France \\ Accepted 20 April 2000.
}

\begin{abstract}
We previously reported that the signal transduction of cryptogein, an elicitor of defense reactions in Nicotiana tabacum cells, involves upstream protein phosphorylation. In the present study, induction of these early physiological events was further investigated with inhibitors of protein phosphatase (PP), okadaïc acid, and calyculin A. Calyculin A mimicked the effects of cryptogein, inducing an influx of calcium, an extracellular alkalinization, and the production of active oxygen species (AOS), suggesting that during cryptogein signal transduction the balance between specific protein kinase (PK) and PP activities was modified. To identify the phosphorylated proteins that could be involved early in the elicitor signaling pathway, we analyzed by 2-D electrophoresis the in vivo phosphorylation status of proteins after cryptogein, staurosporine, and calyculin A treatments of tobacco cells $(5 \mathrm{~min})$. Of about 100 phospho-labeled polypeptides, 19 showed increased ${ }^{32} \mathrm{P}$ incorporation after 5 min of cryptogein treatment. Phosphorylation of 12 of the 19 polypeptides depended upon calcium influx. Staurosporine inhibited the phosphorylations induced by cryptogein whereas calyculin A activated the phosphorylation of 18 of these polypeptides. This study highlighted the role of PKs and/or constitutive active PPs whose activation and inhibition, respectively, resulted in an increased phosphorylation of proteins that may be involved in cryptogein signal transduction. Identification of the phosphoproteins is in progress and will increase our knowledge of signal transduction pathways implicated in plant defense responses.
\end{abstract}

During evolution, plants have mounted a complex array of defense reactions in response to invading pathogens such as bacteria, fungi, viruses, and insects. Activation of host defense responses results from molecular recognition of the invading pathogen (Keen 1992; Boller 1995), and leads to reactions that include production of phytoalexins, synthesis of pathogenesisrelated (PR) proteins with antimicrobial activities (Fritig et al. 1998), phenolic compound depositions, and reinforcement of plant cell walls (Hammond-Kosack and Jones 1996). The incompatible interaction of a plant and a microorganism is often

Corresponding author: Angela Lebrun-Garcia

E-mail: lebrun@dijon.inra.fr associated with the hypersensitive response (HR) characterized by the death of plant cells at the site of contact, thus restricting pathogen development. Signal transduction pathways, related to the perception of pathogens, include changes in protein phosphorylation status, modifications in ion fluxes, increase in cytosolic $\mathrm{Ca}^{2+}$ concentration, depolarization of the plasma membrane, production of active oxygen species (AOS), and modifications of gene expression (reviewed in Hammond-Kosack and Jones 1997; Yang et al. 1997). Posttranslational protein modification by phosphorylation is a general mechanism in the reception/transduction of signals originating from pathogens (Stone and Walker 1995). Thus, identification of the protein kinases (PKs), protein phosphatases (PPs), and their corresponding protein substrates involved in the early steps of signal transduction appears to be of prime importance. PKs implicated in defense mechanisms consist of many types and include members of resistance $(R)$ class gene products; e.g., proteins involved in the resistance of a plant against a pathogen expressing an avirulence (avr) gene in a specific $a v r$ gene- $R$ gene relationship (Flor 1971), such as Pto and Xa21 proteins, which are products of $R$ genes involved in the resistance of tomato and rice against Pseudomonas syringae pv. tomato and Xanthomonas campestris pv. oryzae, respectively (Martin et al. 1993; Song et al. 1995). Members of the mitogen-activated protein kinase (MAPK) module have also been involved in plant defense reactions (for review see Jonak et al. 1999). Likewise, $\mathrm{Ca}^{2+}$-dependent and PKC-type PKs were shown to participate in elicitor signal transduction (Subramaniam et al. 1997; Xing et al. 1997). Elicitors of plant defense reactions, derived from pathogens or challenged plants, are able to induce resistance in plants and have been extensively used to study signal transduction pathways in plants (Ebel and Scheel 1997). Among elicitors, elicitins, which are a class of small, proteinaceous elicitors purified from culture filtrates of Phytophthora spp., when applied to tobacco plants, trigger the appearance of small, foliar necroses characteristic of the HR, together with the protection of tobacco plants against various pathogens (for reviews see Yu 1995; Ricci 1997). The mode of action of one of these elicitins, cryptogein, was mainly studied with Nicotiana tabacum cv. Xanthi cell suspensions. After binding on high affinity sites on the plasma membrane (Wendehenne et al. 1995; Bourque et al. 1998, 1999), cryptogein induces, in the first minutes, many events such as protein phosphorylation (Viard 
et al. 1994; Lebrun-Garcia et al. 1998; Zhang et al. 1998), ionic exchange modifications (Blein et al. 1991) including a calcium influx and an anion efflux (Tavernier et al. 1995; Pugin et al. 1997), and activation of a plasma membrane NADPH oxidase responsible for a transient production of AOS (Bottin et al. 1994; Pugin et al. 1997). These early effects were inhibited by staurosporine, a protein kinase inhibitor (Viard et al. 1994; Tavernier et al. 1995), indicating that phosphorylation reactions occurred upstream from these effects.

Modifications of the phosphorylation status of proteins have often been reported during elicitor treatments (Dietrich et al. 1990; Felix et al. 1991, 1993; Reymond et al. 1995). Enhanced or decreased phosphorylation of different proteins occurred rapidly after elicitation of spruce cells (Salzer et al. 1996). The application of yeast extract, xylanase, and chitotetraose to tomato cells resulted in drastic changes of phosphoprotein labeling (Felix et al. 1991, 1993). A calreticulinlike protein has recently been reported to be dephosphorylated in response to oligogalacturonides in tobacco cells. Moreover, during this elicitor treatment large differences were observed in the phosphoprotein patterns, reflecting a cascade of phosphorylation/dephosphorylation events from the signal reception to the final output response (Droillard et al. 1997).

To study the involvement of protein phosphorylation/ dephosphorylation in the early steps of the cryptogein signal transduction and to identify the phosphoproteins implicated in this process, we tested the ability of PK and PP inhibitors to mimic or to affect early events induced by cryptogein (calcium influx, AOS production, and extracellular alkalinization) and compared 2-D electrophoresis patterns of in vivo phosphorylated proteins during these different treatments (5 min). Our results show that while staurosporine, a PK inhibitor, inhibited all the effects induced by cryptogein, these effects were mimicked by calyculin A, a PP inhibitor. Moreover, cryptogein induced the phosphorylation of 19 polypeptides that, with one exception, were also phosphorylated after calyculin A treatment. In cryptogein-treated cells, the phosphorylation of 12 of these polypeptides depends on calcium influx, indicating they operate downstream from the calcium influx, with the other polypeptides operating upstream or independently. Taken together, these results show the early involvement of PKs and PPs whose levels of activity may modify the phosphorylation status of proteins implicated in the elicitor signal transduction pathway.

\section{RESULTS}

To study the involvement of protein phosphorylation/dephosphorylation processes in cryptogein signal transduction, we first monitored the dependence of early physiological effects (calcium influx, AOS production, and extracellular alkalinization) on protein dephosphorylation. These early steps were shown previously to be inhibited by PK inhibitors (Viard et al. 1994; Tavernier et al. 1995; and our data, not shown). Using cells treated with PP inhibitors, we showed that these early events could be induced by calyculin A, a PP inhibitor. In a second step, phospho-labeled proteins from cryptogeintreated and PP or PK inhibitor-treated cells (5 min) were analyzed by 2-D electrophoresis.
Involvement of protein dephosphorylation in extracellular alkalinization, AOS production and calcium uptake:

\section{Extracellular alkalinization.}

Calyculin A and okadaïc acid, two inhibitors of protein phosphatases types 1 and $2 \mathrm{~A}$, were used alone or in the presence of cryptogein. When added alone, okadaïc acid had no effect (data not shown), whereas calyculin A alone used at 500 $\mathrm{nM}$ induced an alkalinization of the extracellular medium, significant after $5 \mathrm{~min}$ of treatment, that reached a plateau at around pH 6.9 after $20 \mathrm{~min}$ (Fig. 1A). The intensity of this effect was dose-dependent (data not shown). Cryptogein used at a saturating concentration $(50 \mathrm{nM})$ induced an alkaliniza-
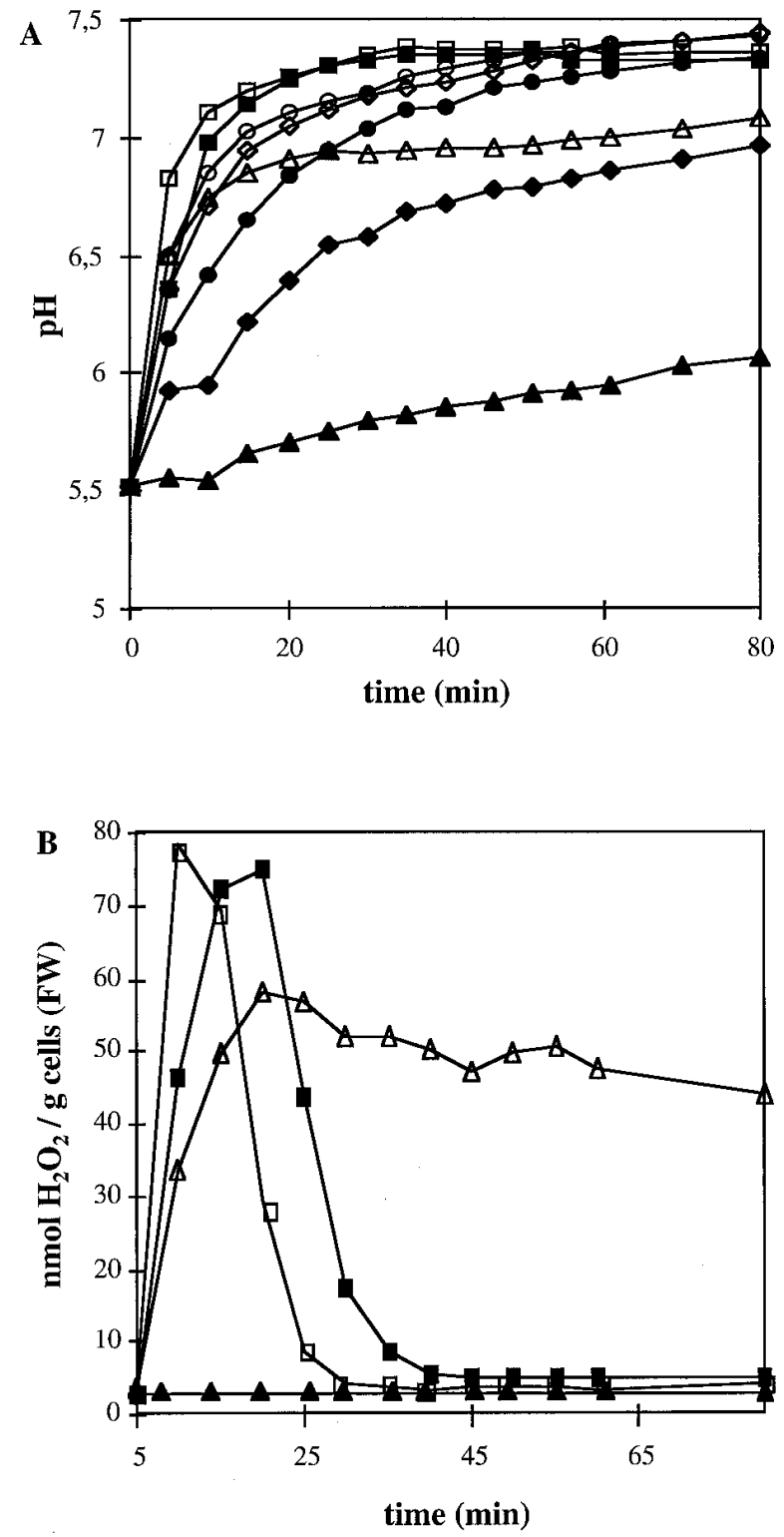

Fig. 1. A, Extracellular alkalinization in tobacco cell suspensions: control $(\mathbf{\Delta})$, cells treated by $50 \mathrm{nM}(\boldsymbol{\square}), 2.5 \mathrm{nM}(\bullet)$, or $1 \mathrm{nM}(\bullet)$ cryptogein or $500 \mathrm{nM}$ calyculin $\mathrm{A}(\Delta)$. Co-treatments corresponded to $500 \mathrm{nM}$ calyculin A in presence of cryptogein $50 \mathrm{nM}(\square), 2.5 \mathrm{nM}(O)$, or $1 \mathrm{nM}$ $(\diamond)$. B, Time course of $\mathrm{H}_{2} \mathrm{O}_{2}$ production measured by chemiluminescence of luminol in tobacco cell suspensions. Symbols as in (A). FW (fresh weight). 
tion that stabilizes at $\mathrm{pH} 7.3$ (Fig. 1A). To test whether the effect of calyculin A and cryptogein could be cumulative, cryptogein was used at non-saturating (1 and $2.5 \mathrm{nM})$ and saturating $(50 \mathrm{nM})$ concentrations together with $500 \mathrm{nM}$ calyculin A. A faster alkalinization of the extracellular medium was observed when cells were co-treated with calyculin A and cryptogein at different concentrations, compared with the alkalinization induced by cryptogein used at the equivalent concentration. In cells co-treated with calyculin $\mathrm{A}$ and 1 $\mathrm{nM}$ cryptogein, the $\mathrm{pH}$ plateau reached the maximal $\mathrm{pH}$ value obtained with $50 \mathrm{nM}$ cryptogein, whereas this $\mathrm{pH}$ value was not reached with $500 \mathrm{nM}$ calyculin A or $1 \mathrm{nM}$ cryptogein.

\section{AOS production.}

AOS production is a rapid reaction of plants to infection or elicitor treatments (Sutherland 1991; Mehdy 1994; Lamb and Dixon 1997), which was also reported in elicitin-treated tobacco cells (Bottin et al. 1994; Bourque et al. 1998). We chose to measure AOS production by monitoring chemiluminescence of luminol on the one hand and pyranine fluorescence decrease on the other hand, both compounds being oxidized by plant peroxidases in the presence of $\mathrm{H}_{2} \mathrm{O}_{2}$ released in the extracellular medium (Figs. $1 \mathrm{~B}$ and 2). Both methods were complementary: the first permits the monitoring of $\mathrm{H}_{2} \mathrm{O}_{2}$ production over long periods by the addition of fresh luminol at each measurement time; the second allows measurement of $\mathrm{H}_{2} \mathrm{O}_{2}$ production continuously over periods lasting about 10 min and determination of the exact starting point of $\mathrm{H}_{2} \mathrm{O}_{2}$ production. The decrease of pyranine fluorescence was related to $\mathrm{H}_{2} \mathrm{O}_{2}$ production and was expressed as relative units of fluorescence per second. The sensitivity of $\mathrm{H}_{2} \mathrm{O}_{2}$ detection with both methods was comparable, with about $10^{-7} \mathrm{M} \mathrm{H}_{2} \mathrm{O}_{2}$ being the lowest detectable concentration.

$\mathrm{H}_{2} \mathrm{O}_{2}$ production, monitored with the chemiluminescence of luminol, is shown in Figure 1B. Cell suspensions were treated with $500 \mathrm{nM}$ calyculin A, $50 \mathrm{nM}$ cryptogein or both compounds. Calyculin A induced a sustained production of $\mathrm{H}_{2} \mathrm{O}_{2}$. In comparison, cryptogein induced a transient oxidative burst that peaked at $20 \mathrm{~min}$ and lasted for $40 \mathrm{~min}$. When added together, cryptogein and calyculin A promoted a transient production of $\mathrm{H}_{2} \mathrm{O}_{2}$ that peaked 10 min earlier than in cryptogeinor calyculin A-treated cells. The amplitude of the burst obtained in co-treated cells was comparable to that of the cryptogein-induced burst.

$\mathrm{H}_{2} \mathrm{O}_{2}$ production was also measured by monitoring the rate of fluorescence decrease (RFD) of pyranine in cells treated with increasing concentrations of cryptogein or calyculin A (Fig. 2). The RFD increased with cryptogein concentration (Fig. 2A). The maximal RFD was obtained with $50 \mathrm{nM}$ cryptogein, which was the concentration that triggered the highest AOS production when measured with chemiluminescence of luminol. Moreover, the lag period of $\mathrm{H}_{2} \mathrm{O}_{2}$ production decreased with increasing cryptogein concentrations (Fig. 2A), from 290 to $180 \mathrm{~s}$ with 1 to $50 \mathrm{nM}$ cryptogein. When cell suspensions were treated with calyculin $\mathrm{A}$ alone, the RFD increased with the concentration of calyculin A (Fig. 2B). The lag period for $\mathrm{H}_{2} \mathrm{O}_{2}$ production decreased with increasing concentrations of calyculin A: from 150 to $30 \mathrm{~s}$ with $75 \mathrm{nM}$ to 1 $\mu \mathrm{M}$ calyculin A (Fig. 2B). Okadaïc acid (1.6 $\mu \mathrm{M})$ had no effect on AOS production (data not shown).

\section{$\mathrm{Ca}^{2+}$ influx.}

Treatments of tobacco cells with $50 \mathrm{nM}$ cryptogein or 500 $\mathrm{nM}$ calyculin A resulted in an increase of ${ }^{45} \mathrm{Ca}^{2+}$ influx (Fig. 3A). The ${ }^{45} \mathrm{Ca}^{2+}$ influx was lower in calyculin A-treated cells than in cryptogein-treated cells. Cryptogein-induced $\mathrm{Ca}^{2+}$ influx was sustained during $1 \mathrm{~h}$ whereas calcium influx did not increase after $15 \mathrm{~min}$ in calyculin A-treated cells. Addition of $2 \mathrm{mM}$ EGTA (ethylene glycol-bis( $\beta$-aminoethyl ether)$N, N, N^{\prime}, N^{\prime}$-tetraacetic acid) suppressed both calyculin A- and cryptogein-induced $\mathrm{Ca}^{2+}$ influx (Fig. 3A). When $50 \mathrm{nM}$ cryptogein and $500 \mathrm{nM}$ calyculin A were used together, an additive calcium influx could not be observed, probably because of the intense calcium entry already promoted by cryptogein (data not shown). Nevertheless, when cryptogein was used at a small concentration $(0.25 \mathrm{nM})$ together with $500 \mathrm{nM}$ calyculin A, additive effects of cryptogein and calyculin A were clearly observed (Fig. 3B).

\section{Protein phosphorylations in cryptogein-treated and PP/PK inhibitor-treated cells.}

The similarity between the effects of calyculin A and cryptogein suggests that these compounds should increase the phosphorylation level of identical polypeptide(s), either by an
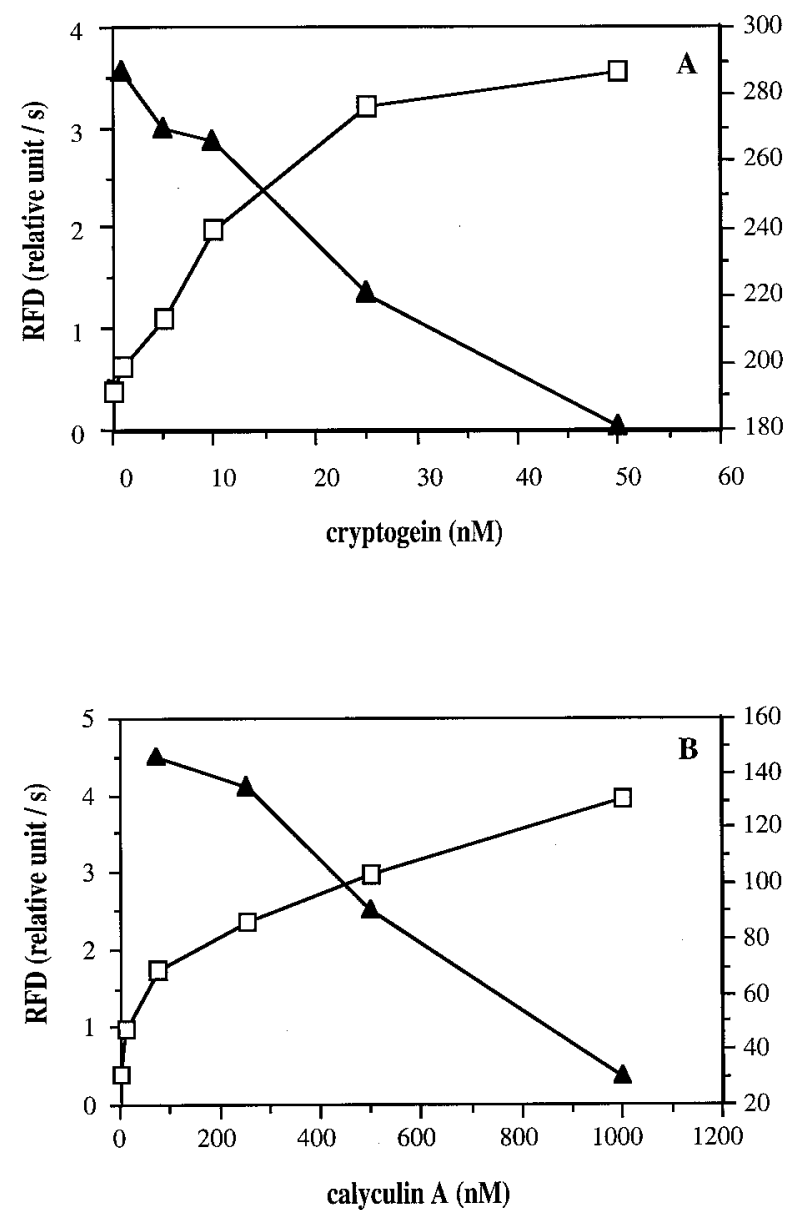

Fig. 2. Rate of fluorescence decrease (RFD) of pyranine ( $\square$ ) and lag time of $\mathrm{H}_{2} \mathrm{O}_{2}$ production $(\boldsymbol{\Delta})$ in (A) cryptogein or (B) calyculin Atreated cells. Decrease of fluorescence of pyranine was continuously monitored; initial slope of the fluorescence decrease was used to determine RFD. Experiments were conducted three times. 
inhibition of PPs and/or an activation of PKs. To verify this assumption and to identify these polypeptides involved in the cryptogein signal transduction, we performed in vivo phosphorylation experiments by adding radioactive phosphorus $\left({ }^{32} \mathrm{P}\right)$ to tobacco cell suspensions before cryptogein or PP/PK inhibitor treatments. Protein extracts were prepared from cells treated (or not) for $5 \mathrm{~min}$ with $50 \mathrm{nM}$ cryptogein, $500 \mathrm{nM}$ calyculin $\mathrm{A}, 1.5 \mu \mathrm{M}$ staurosporine, or $1.5 \mu \mathrm{M}$ staurosporine and $50 \mathrm{nM}$ cryptogein. After 2-D electrophoresis, more than 1,000 spots were visualized by silver staining, including about 100 phospho-labeled polypeptides. Polypeptide labeling intensities were estimated in comparison to those in control experiments and are reported in Table 1. Compared with control cells, the


Fig. 3. A, Calcium influx in tobacco cells treated with $50 \mathrm{nM}$ cryptogein $(\square)$ or $500 \mathrm{nM}$ calyculin $\mathrm{A}(\boldsymbol{\Delta})$, in the absence (black symbols) or presence (open symbols) of $2 \mathrm{mM}$ EGTA. Control cells $(\diamond)$. B, Calcium influx in tobacco cells treated with $0.25 \mathrm{nM}$ cryptogein $(\diamond), 500 \mathrm{nM}$ calyculin $\mathrm{A}(\boldsymbol{\Delta})$, or $0.25 \mathrm{nM}$ cryptogein in the presence of $500 \mathrm{nM}$ calyculin A $(\bullet)$. Control cells $(\diamond)$. DW: dry weight.
${ }^{32} \mathrm{P}$-labeling level of many polypeptides increased in cryptogein-treated cells (Fig. 4A, B). The spots corresponding to polypeptides that showed the highest labeling increase with the best reproducibility were numbered from 1 to 19 . The apparent molecular mass (MM) varied from 27 to $63 \mathrm{kDa}$ with a mainly acidic pI that ranged from 3.7 to 6.5 (Table 1). Treatment of tobacco cells with $1.5 \mu \mathrm{M}$ staurosporine alone or with $50 \mathrm{nM}$ cryptogein and $1.5 \mu \mathrm{M}$ staurosporine resulted in a low labeling of polypeptides (Table 1) similar to that observed in control experiments. In contrast, cell treatments with $500 \mathrm{nM}$ calyculin A yielded 2-D patterns similar to those obtained with cryptogein (Fig. 4C). Except for spot number 1, whose labeling intensity did not increase in calyculin A-treated cells, cryptogein and calyculin A activated the phosphorylation rate of 18 polypeptides with the same $\mathrm{MM}$ and $\mathrm{pI}$, respectively (Fig. 4B, C). For some of these polypeptides, the labeling level was higher in cryptogein-treated cells than in calyculin A-treated cells. In addition, calyculin A induced the phosphorylation of a number of polypeptides, named "a" to "d" (Fig. 4C).

\section{$\mathrm{Ca}^{2+}$ dependence of protein phosphorylation in cryptogein-treated cells.}

To identify the polypeptides whose phosphorylation depends on $\mathrm{Ca}^{2+}$ influx, we performed in vivo phosphorylations in the presence of lanthanum, which was previously shown to block cryptogein-induced calcium influx and dependent events (Tavernier et al. 1995; Pugin et al. 1997). Data are summarized in Table 1 . When cells were treated with $50 \mathrm{nM}$ cryptogein and $2 \mathrm{mM} \mathrm{La}^{3+}$, 2-D electrophoresis revealed that the phosphorylation of 12 of the 19 phosphorylated polypeptides

Table 1. Characteristics of phosphorylated polypeptides from tobacco cells analyzed by 2-D electrophoresis: molecular mass (MM), pI, and labeling intensity after different treatments

\begin{tabular}{lcccccccc}
\hline $\begin{array}{l}\text { Spot } \\
\text { no. }\end{array}$ & pI & $\begin{array}{l}\text { MM } \\
\text { (kDa) }\end{array}$ & Control & Cry & Cal & Stau & $\begin{array}{c}\text { Cry+ } \\
\text { Stau }\end{array}$ & $\begin{array}{c}\text { Cry+ } \\
\text { La }^{3+}\end{array}$ \\
\hline 1 & 3.70 & 27.6 & - & ++++ & - & - & - & - \\
2 & 4.13 & 40.6 & + & +++ & +++ & + & + & ++ \\
3 & 4.25 & 63.0 & + & +++ & +++ & + & + & - \\
4 & 4.31 & 61.6 & + & +++ & +++ & + & + & +++ \\
5 & 4.37 & 60.3 & + & +++ & +++ & + & + & +++ \\
6 & 4.61 & 56.7 & - & ++++ & +++ & - & - & - \\
7 & 4.70 & 55.2 & - & ++++ & +++ & - & - & - \\
8 & 4.82 & 57.1 & - & +++ & +++ & - & - & - \\
9 & 4.90 & 56.3 & - & +++ & +++ & - & - & - \\
10 & 5.11 & 53.8 & + & +++ & ++ & - & - & - \\
11 & 5.14 & 53.8 & + & +++ & ++ & - & - & - \\
12 & 5.17 & 53.8 & + & +++ & ++ & - & - & - \\
13 & 5.12 & 52.4 & + & +++ & ++ & - & - & - \\
14 & 5.15 & 52.4 & + & +++ & ++ & - & - & - \\
15 & 5.18 & 52.4 & + & +++ & ++ & - & - & - \\
16 & 5.80 & 32.3 & - & ++ & ++ & - & - & + \\
17 & 5.94 & 32.3 & - & ++ & ++ & - & - & + \\
18 & 6.36 & 32.3 & - & ++ & ++ & - & - & + \\
19 & 6.50 & 32.3 & - & ++ & ++ & - & - & + \\
\hline
\end{tabular}

${ }^{\mathrm{a}} \mathrm{MM}$ was estimated with markers of MM (Sigma, St. Quentin-Fallavier, France), and is mean value of four to 10 independent 2-D electrophoresis. pI was estimated with markers (Sigma). Radioactivity associated to each spot was quantified with a PhosphorImager (Molecular Dynamics, Boundoufle, France). Five levels of labeling intensity were defined from background level (-) to highest phosphorylation level (++++). 2-D electrophoresis was repeated four to 10 times depending on the treatment. Cry = cryptogein; Cal = calyculin A; Stau = staurosporine. 
(numbers 1, 3, and 6 to 15) was strongly decreased, suggesting that the process leading to their phosphorylation was $\mathrm{Ca}^{2+}$ dependent. The other polypeptides (numbers 2, 4, 5, and 16 to 19) showed a level of phosphorylation comparable to that observed in cryptogein-treated cells without $\mathrm{La}^{3+}$, indicating that the phosphorylation of these seven polypeptides occurs upstream or independently of the $\mathrm{Ca}^{2+}$ influx.

\section{DISCUSSION}

This work investigated the involvement of protein phosphorylation/dephosphorylation mechanisms in a cellular signaling process activated by an elicitor and leading to plant defense expression. We used PK and PP inhibitors, staurosporine and calyculin A, that suppress or mimic, respectively, the effects due to cryptogein. Staurosporine inhibited $\mathrm{Ca}^{2+}$ uptake, extracellular alkalinization, AOS production, and protein phosphorylation induced by cryptogein. On the other hand, calyculin A, a potent inhibitor of PP1 and PP2A (50\% inhibitory concentration $\left[\mathrm{IC}_{50}\right] \approx 0.1$ to $\left.0.3 \mathrm{nM}\right)$, triggered all the above effects. Okadaïc acid, another potent inhibitor of PP2A ( $\mathrm{IC}_{50} \approx$
0.1 to $1.0 \mathrm{nM}$ ), but less efficient on PP1 ( $\mathrm{IC}_{50} \approx 10$ to $100 \mathrm{nM}$ ) (Smith and Walker 1996), was unable to induce AOS production or extracellular medium alkalinization even when used at 1.6 $\mu \mathrm{M}$. These results suggested the inhibition of a PP of type 1 in cryptogein signaling. However, cryptogein is not a PP inhibitor (C. MacKintosh, personal communication). Differences between calyculin A and cryptogein effects were accounted for mainly by the intensity and kinetics of induced effects and could have different origins: cryptogein is presumed to interact first with a receptor on the plasma membrane (Wendehenne et al. 1995; Bourque et al. 1998, 1999), whereas calyculin A inhibits a PP(s) probably acting downstream from the receptor in the signaling cascade. Thus, depending on the treatment, the PPs probably undergo different levels of inhibition and feed-back regulation, leading to different amplifications of the signal. Calyculin A may also act on other PPs. Nevertheless, when cryptogein and calyculin A were added together, additive or combined effects were monitored. Extracellular alkalinization and $\mathrm{Ca}^{2+}$ influx in the presence of cryptogein and calyculin A were assayed at low cryptogein concentrations to improve the sensitivity of meas-


Fig. 4. 2-D electrophoresis patterns of ${ }^{32} \mathrm{P}$-labeled polypeptides from (A) non-treated tobacco cells, or tobacco cells treated with (B) $50 \mathrm{nM}$ cryptogein or (C) $500 \mathrm{nM}$ calyculin A during $5 \mathrm{~min}$. Phospho-labeled proteins were detected after 4- to 7-day exposure with a storage phosphor screen (Molecular Dynamics, Bondoufle, France). 2-D electrophoresis was conducted four to 10 times depending on the treatment. 
urements, because the effects obtained with $50 \mathrm{nM}$ cryptogein were maximal or too strong, compared with the effects of calyculin A. Extracellular alkalinization was faster in co-treated cells than in cells treated with one compound (Fig. 1A). Moreover, this co-treatment led to a maximal extracellular alkalinization comparable to what was obtained with $50 \mathrm{nM}$ cryptogein, whereas the maximal alkalinization in the presence of $500 \mathrm{nM}$ calyculin A or $1 \mathrm{nM}$ cryptogein was lower. $\mathrm{H}_{2} \mathrm{O}_{2}$ production induced in the presence of both cryptogein and calyculin A was transient, with an amplitude comparable to the one obtained in the presence of cryptogein alone, but occurred earlier. This effect is consistent with the faster AOS production induced by calyculin $\mathrm{A}$, as observed in fluorescence experiments (Fig. 2B). Longer co-treatments revealed a clear cryptogein dominant effect on AOS production that remained transient. This property may be related to the desensitization processes triggered in cryptogein-treated cells (Binet et al. 1998). Considering the calcium uptake, an additive effect was monitored in cells treated with $500 \mathrm{nM}$ calyculin A and $1 \mathrm{nM}$ cryptogein (Fig. 3B). The calcium influx induced by cryptogein, which has been shown to trigger all the other described effects of cryptogein except the first phosphorylation step(s), is supposed to act through a specific pathway, as calcium ionophores did not trigger these downstream effects (Tavernier et al. 1995). Thus, the ability of calyculin A to induce a calcium influx and the concomitant effects observed in cryptogein-treated cells, and the fact that the co-treatments always resulted either in a higher and/or faster response, provided that the effects were not saturating, suggested that some protein targets involved in the first steps of cryptogein and calyculin A signal transduction could be common.

To identify the phosphoproteins involved in cryptogein and/or calyculin A signaling pathways, 2-D electrophoresis was performed after in vivo phospholabeling of proteins treated for 5 min with cryptogein or calyculin A. This period corresponded to approximately the lag period before the detection of ion fluxes and AOS production. The 2-D electrophoretic patterns revealing phosphoproteins in calyculin Atreated cells were very close to those of cryptogein-treated cells. Eighteen of the 19 polypeptides whose phosphorylation was increased in response to cryptogein were shown to be phosphorylated in response to calyculin A. Most of them have an acidic pI (Table 1). The close apparent MMs of many spots (polypeptide series numbers 10 to 12 and 13 to 15 ), and the small increment in their pI suggested that some of the spots could correspond to the same polypeptides with different levels of phosphorylation, acetylation, or glycosylation. The main differences in phosphorylation induced by cryptogein and calyculin A concern polypeptide number 1, which was phosphorylated only in cryptogein-treated cells, and the presence of additional phosphoproteins in calyculin A-treated cells, suggesting that after sharing common steps leading to similar effects, calyculin A and cryptogein signaling pathways rapidly diverged.

Taking into account that $\mathrm{Ca}^{2+}$ influx, which depends upon protein phosphorylation, is an upstream event in the whole cascade, it was interesting to distinguish polypeptides whose phosphorylation was dependent on or independent of calcium influx. In this aim, we performed in vivo phosphorylation in the presence of lanthanum, which was previously shown to block the cryptogein-induced calcium influx (Tavernier et al.
1995). In the presence of $\mathrm{La}^{3+}, 12$ of the 19 polypeptides had a decreased level of phosphorylation, while seven showed a similar level of phosphorylation. Hence, those seven should be phosphorylated upstream or independently of the calcium influx. The 12 polypeptides whose phosphorylation is calcium dependent might be direct or indirect targets of $\mathrm{Ca}^{2+}$-dependent protein kinase (CDPK), $\mathrm{Ca}^{2+}$-/calmodulin-dependent PK, or PKC or $\mathrm{Ca}^{2+}$-modulated phosphatases.

Changes in the level of phosphorylation of cellular proteins have been observed upon elicitor treatments of a variety of cell cultures (Boller 1995; Sopory and Munshi 1998). In many studies, it was shown that protein kinase inhibitors (K-252a, staurosporine) blocked elicitor-induced ion fluxes, AOS production, or activation of genes involved in defense reactions, while protein phosphatase inhibitors (including calyculin A and okadaïc acid) stimulated the inducible defenses in the absence of elicitors (Levine et al. 1994; Chandra and Low 1995; Gianfagna and Lawton 1995; Mathieu et al. 1996; Conrath et al. 1997; He et al. 1998). These results have been used to argue in favor of continuous phosphorylation/dephosphorylation of proteins in the non-elicited state, the inhibition of dephosphorylation being sufficient to initiate signal transduction (Boller 1995). In cell signaling, negative control has been shown to be appropriate for ensuring the well-timed, quantified, and coordinated responses to a specific stimulus, whereas the positively acting elements are essential to drive signal transduction (Bowler and Chua 1994). In tobacco cells, a PP could negatively regulate a PK that phosphorylates specific polypeptides involved in cryptogein signal transduction, as suggested by calyculin A effects. The negative regulation could concern the receptor or a downstream PK. For examples, KAPP (a kinase associated PP), which interacts with receptor-like kinases (RLKs) such as RLK5 (Stone et al. 1994) and CLAVATA1 (a RLK implicated in meristem and organ development), is a negative regulator of CLAVATA1 signaling (Williams et al. 1997; Stone et al. 1998; Trotochaud et al. 1999); type 2C protein phosphatases (PP2C) have been shown to function as negative regulators in ABA signaling (Leung et al. 1994; Meyer et al. 1994). Alternatively, cryptogein could activate directly the $\mathrm{PK}(\mathrm{s})$ that phosphorylates the targets of the PP(s), or could act independently of a PP.

In conclusion, our results indicate that elicitation of plant defense reactions implicates an increase in the phosphorylation level of polypeptides by activation of PK and/or inhibition of PP activities. The different polypeptides characterized in this work should participate in this signal transduction and their sequencing will allow the identification of proteins involved in cryptogein signal transduction. Microsequences, showing no homology with known proteins, were obtained for two of these polypeptides (numbers 4 and 5). Cloning of the corresponding genes is in progress.

\section{MATERIALS AND METHODS}

\section{Cell culture and treatments.}

Nicotiana tabacum cv. Xanthi cell suspensions were grown in Chandler's medium (Chandler et al. 1972) on a rotary shaker (150 rpm; GFL3020; GFL, Burgwedel, Germany; $25^{\circ} \mathrm{C}$ ) under continuous light (photon flux rate of 30 to 40 $\mu \mathrm{mol} \mathrm{s}{ }^{-1} \mathrm{~m}^{-2}$ ). Cells were maintained in exponential phase and subcultured 1 day prior to utilization. Before treatments, cells 
were washed by filtration in a suspension buffer containing $175 \mathrm{mM}$ mannitol, $0.5 \mathrm{mM} \mathrm{CaCl}_{2}, 0.5 \mathrm{mM} \mathrm{K}_{2} \mathrm{SO}_{4}$, and $2 \mathrm{mM}$ or $50 \mathrm{mM}$ 2-( $N$-morpoholino)ethane-sulfonic acid (MES) $\mathrm{pH}$ 5.75. Cells were resuspended at $0.1 \mathrm{~g}$ (unless indicated) fresh weight $(\mathrm{FW}) \mathrm{ml}^{-1}$ of suspension buffer and equilibrated during $2 \mathrm{~h}$ on a rotary shaker (150 rpm; GFL, Burgwedd, Germany; $24^{\circ} \mathrm{C}$ ). Cryptogein was purified according to Bonnet et al. (1996), and was used in a concentration range from 5 to 50 nM. Staurosporine and calyculin A, dissolved in dimethyl sulfoxide (DMSO), were purchased from Sigma (St. QuentinFallavier, France). Control cells were treated with water or DMSO.

\section{Extracellular alkalinization and AOS measurements.}

Extracellular $\mathrm{pH}$ was directly measured in cell suspensions equilibrated in the low buffered suspension medium.

AOS quantification was performed by a chemiluminescent method, with luminol, a bioluminescent molecule reacting with $\mathrm{H}_{2} \mathrm{O}_{2}$ in the presence of plant cell peroxidases contained in cell suspensions. Erlenmeyer flasks containing 10 to $20 \mathrm{ml}$ of cell suspensions were treated with cryptogein or PP and PK inhibitors. Then, $250 \mu \mathrm{l}$ of cell suspension was withdrawn, mixed with $50 \mu \mathrm{l}$ of $0.3 \mathrm{mM}$ luminol and $350 \mu \mathrm{l}$ of a $\mathrm{pH} 6.5$ buffer containing $175 \mathrm{mM}$ mannitol, $0.5 \mathrm{mM} \mathrm{K}_{2} \mathrm{SO}_{4}, 0.5 \mathrm{mM}$ $\mathrm{CaCl}_{2}, 10 \mathrm{mM} N$-(2-hydroxyethyl)piperazine- $N^{\prime}$-(2-ethanesulfonic acid) (HEPES). AOS production was measured with a luminometer (Lumat LB 9501; EG \& G Berthold, Bad Wilbad, Germany) integrating relative luminescent units over a period of $10 \mathrm{~s}$.

The production of $\mathrm{H}_{2} \mathrm{O}_{2}$ was also followed by monitoring the fluorescence decrease of pyranine $\left(\lambda_{\mathrm{ex}}=405 \mathrm{~nm}\right.$ and $\lambda_{\mathrm{em}}=$ $512 \mathrm{~nm}$ ), a fluorescent probe oxidized by peroxidases. The pyranine fluorescence, which is $\mathrm{pH}$ sensitive, was measured in a buffered medium. Cell suspensions at $0.05 \mathrm{~g} \mathrm{FW} \mathrm{ml}^{-1}$ were equilibrated in $50 \mathrm{mM}$ MES pH 6.0, $175 \mathrm{mM}$ mannitol, 0.5 $\mathrm{mM} \mathrm{K} \mathrm{SO}_{4}$ and $0.5 \mathrm{mM} \mathrm{CaCl}$. A $1.5-\mathrm{ml}$ aliquot of cells, maintained in suspension in a spectrophotometer cuvette by a soft agitation, was mixed with an aqueous solution of pyranine at the final concentration of $1.75 \mu \mathrm{M}$. The pyranine fluorescence was continuously measured for $10 \mathrm{~min}$, with 1-s intervals, after addition of cryptogein or inhibitors.

\section{$\mathrm{Ca}^{2+}$ influx.}

$\mathrm{Ca}^{2+}$ uptake was monitored by addition of ${ }^{45} \mathrm{Ca}^{2+}(0.033$ $\mathrm{MBq} \mathrm{g}^{-1} \mathrm{FW}$ of cells) $5 \mathrm{~min}$ before cryptogein treatment. After various periods of treatment (0 to $90 \mathrm{~min}$ ), duplicate samples of $2 \mathrm{ml}$ of cell suspensions were filtrated on GF/A glass microfiber filters (Whatman, Maidstone, England) and washed once for $1 \mathrm{~min}$ and twice for $20 \mathrm{~s}$, with $10 \mathrm{ml}$ of ice-cold 2 $\mathrm{mM} \mathrm{LaCl} 3$ in assay medium without $\mathrm{Ca}^{2+}$ to remove extracellular $\mathrm{Ca}^{2+}$. Cells were scraped from the filters, placed in scintillation vials, dried, and weighed. Ten milliliters of Ready Safe cocktail (Beckman, Fullerton CA) was added to the vials, which were gently shaken overnight before the radioactivity was counted in an LS 600 TA (Beckman) scintillation counter.

\section{In vivo protein phosphorylation.}

Cells were equilibrated for $2 \mathrm{~h}$ in the low buffered suspension medium on a rotary shaker (150 rpm; GFL, Burgwedd, Germany; $24^{\circ} \mathrm{C}$ ) and then pre-incubated for $10 \mathrm{~min}$ with ${ }^{32} \mathrm{P}$ [orthophosphate] $\left(111 \mathrm{GBq} \mathrm{mmol}^{-1}\right)$ at $0.37 \mathrm{MBq} \mathrm{ml}^{-1}$ cell suspension. Cells were treated or not (control cells) with 50 $\mathrm{nM}$ cryptogein and/or staurosporine $(1.5 \mu \mathrm{M})$ or PP inhibitors (calyculin A and okadaïc acid at concentration ranges from 75 to $1000 \mathrm{nM}$ and 10 to $1800 \mathrm{nM}$, respectively). After a 5-min treatment, $4 \mathrm{ml}$ of cell suspension was removed and filtrated on GF/A filters; cells were immediately frozen in liquid nitrogen. Then, cells were ground and covered with trichloroacetic acid (TCA) at a final concentration of $10 \%$. After precipitation for $1 \mathrm{~h}$ at $4^{\circ} \mathrm{C}$, proteins were sedimentated by centrifugation $(10 \mathrm{~min}, 10,000 \times g)$. The pellet was washed twice with 1 $\mathrm{ml}$ of cold acetone, dried, and solubilized for $16 \mathrm{~h}$ under permanent agitation in a buffer suited for 2-D electrophoresis containing $9 \mathrm{M}$ urea, 4\% 3-[(3-cholamidopropyl)dimethylammonio]-1-propanesulfonate (CHAPS), $0.5 \%$ Triton X-100, $20 \mathrm{mM}$ dithiothreitol (DTT), 1.2\% Pharmalytes 3-10. The samples were then centrifuged at $13,000 \times g$ for $30 \mathrm{~min}$, and supernatants containing the solubilized proteins were collected. Proteins were quantified by a modified Bradford method (Ramagali and Rodrigues 1985). Radioactivity was measured in a mixture containing $5 \mu \mathrm{l}$ of the supernatant and 5 $\mathrm{ml}$ of Ready Safe cocktail, with a scintillation counter (LS 6000 TA; Beckman).

\section{Two-dimensional electrophoresis.}

First dimension was performed on non-linear $\mathrm{pH}$ immobilin strips (18 cm, pH 3 to 10$)$ according to the supplier (Amersham Pharmacia Biotech, Orsay, France), with 100 to $200 \mu \mathrm{g}$ of solubilized proteins. Comparison of different treatments was performed with equal amounts of protein. After isofocusing $(100 \mathrm{kVh})$, the strips were equilibrated for $10 \mathrm{~min}$ in $50 \mathrm{mM}$ Tris- $\mathrm{HCl} \mathrm{pH} 6.8,6 \mathrm{M}$ urea, $30 \%$ glycerol, $2 \%$ sodium dodecyl sulfate (SDS), $2 \%$ DTT and then for $5 \mathrm{~min}$ in the same solution with $2.5 \%$ iodoacetamide instead of DTT. The second dimension was performed at constant voltage (250 V) for $3 \mathrm{~h}$, on $160 \times 140 \times 1.5 \mathrm{~mm}$ gels containing $10 \%$ polyacrylamide separating gel according to Laemmli conditions (Laemmli 1970).

The gels were silver-stained, and/or dried for immediate exposure with storage phosphor screens (Molecular Dynamics, Bondoufle, France). For silver-staining, proteins were fixed for $1 \mathrm{~h}$ in a $30 \%$ ethanol and $10 \%$ acetic acid solution. Sensitization was performed overnight in $0.5 \%$ glutaraldehyde, $0.5 \mathrm{M}$ potassium acetate, $20 \%$ ethanol, $0.3 \% \mathrm{~K}_{2} \mathrm{~S}_{4} \mathrm{O}_{6}$. Then, gels were rinsed six times for $20 \mathrm{~min}$, impregnated for 1 to $2 \mathrm{~h}$ with $0.2 \% \mathrm{AgNO}_{3}$ and $37 \% \mathrm{HCHO}$, and rinsed $10 \mathrm{~s}$ with distilled water. Coloration was developed in $3 \% \mathrm{~K}_{2} \mathrm{CO}_{3}$, $37 \% \mathrm{HCHO}$ and $12.5 \mathrm{mg} \mathrm{ml}^{-1} \mathrm{Na}_{2} \mathrm{~S}_{2} \mathrm{O}_{3}, 5 \mathrm{H}_{2} \mathrm{O}$. The staining reaction was stopped by incubating gels in 5\% Tris and $2.5 \%$ acetic acid for $30 \mathrm{~min}$.

Phospho-labeled proteins were detected after a 4- to 7-day exposure with a storage phosphor screen. The phosphorylated proteins were analyzed and their labeling intensity was quantified with a PhosphorImager 445 SI (Molecular Dynamics).

\section{ACKNOWLEDGMENTS}

We are indebted to M. Ponchet (INRA, Antibes) for the gift of cryptogein, and to V. Santoni (INRA, Montpellier) for technical assistance in 2-D electrophoresis. We thank M.-J. Farmer for revising the English. F. L.-O. is supported by a grant from the Ministère de l'Enseignement Supérieur et de la Recherche. This work was supported by INRA and Conseil Régional de Bourgogne. 


\section{LITERATURE CITED}

Binet, M. N., Bourque, S., Lebrun-Garcia, A., Chiltz, A., and Pugin, A. 1998. Comparison of the effects of cryptogein and oligogalacturonides on tobacco cells and evidence of different forms of desensitization induced by these elicitors. Plant Sci. 117:33-41.

Blein, J. P., Milat, M. L., and Ricci, P. 1991. Responses of cultured tobacco cells to cryptogein, a proteinaceous elicitor from Phytophthora cryptogea. Possible plasmalemma involvement. Plant Physiol. 95: 486-491.

Boller, T. 1995. Chemoperception of microbial signals in plant cells. Annu. Rev. Plant Physiol. Plant Mol. Biol. 46:189-214.

Bonnet, P., Bourdon, E., Ponchet, M., Blein, J.-P., and Ricci, P. 1996. Acquired resistance triggered by elicitins in tobacco and other plants. Eur. J. Plant Pathol. 102:181-192.

Bottin, A., Véronési, C., Pontier, D., Esquerré-Tugayé, M. T., Blein, J. P., Rustérucci, C., and Ricci, P. 1994. Differential responses of tobacco cells to elicitors from two Phytophthora species. Plant Physiol. Biochem. 32:373-378.

Bourque, S., Binet, M.-N., Ponchet, M., Pugin, A., and Lebrun-Garcia, A. 1999. Characterization of the cryptogein binding sites on plant plasma membranes. J. Biol. Chem. 274:34699-34705.

Bourque, S., Ponchet, M., Binet, M. N., Ricci, P., Pugin, A., and LebrunGarcia, A. 1998. Comparison of binding properties and early biological effects of elicitins in tobacco cells. Plant Physiol. 118:1317-1326.

Bowler, C., and Chua, N.-H. 1994. Emerging themes of plant signal transduction. Plant Cell 6:1529-1541.

Chandler, M. T., Tandeau de Marsac, N., and De Kouchkovsky, Y. 1972. Photosynthetic growth of tobacco cells in liquid suspension. Can. J. Bot. 50:2265-2270.

Chandra, S., and Low, P. 1995. Role of phosphorylation in elicitation of oxidative burst in cultured soybean cells. Proc. Natl. Acad. Sci. USA 92:4120-4123.

Conrath, U., Silva, H., and Klessig, D. F. 1997. Protein dephosphorylation mediates salicylic acid-induced expression of $P R-1$ genes in tobacco. Plant J. 11:747-757.

Dietrich, A., Mayer, J. E., and Hahlbrock, K. 1990. Fungal elicitor triggers rapid, transient, and specific protein phosphorylation in parsley cell suspension cultures. J. Biol. Chem. 265:6360-6368.

Droillard, M. J., Güclü, J., Le Caer, J. P., Mathieu, Y., Guern, J., and Laurière, C. 1997. Identification of calreticulin-like protein as one of the phosphoproteins modulated in response to oligogalacturonides in tobacco cells. Planta 202:341-348.

Ebel, J., and Scheel, D. 1997. Signals in host-parasite interactions. Pages 85-105 in: The Mycota. Vol. 5. Part A. Plant Relationships. G. C. Carroll and P. Tudzunski, eds. Springer-Verlag, Berlin.

Felix, G., Grosskopf, D. G., Regenass, M., and Boller, T. 1991. Rapid changes of protein phosphorylation are involved in transduction of the elicitor signal in plant cells. Proc. Natl. Acad. Sci. USA 88:88318834.

Felix, G., Regenass, M., and Boller, T. 1993. Specific perception of subnamolar concentrations of chitin fragments by tomato cells: Induction of the extracellular alkalinization, changes in protein phosphorylation, and establishment of a refractory state. Plant J. 4:307-316.

Flor, H. H. 1971. Current status of gene-for-gene concept. Annu. Rev. Phytopathol. 9:275-296.

Fritig, B., Heitz, T., and Legrand, M. 1998. Antimicrobial proteins in induced plant defense. Curr. Opin. Immunol. 10:16-22.

Gianfagna, T. J., and Lawton, M. A. 1995. Specific activation of soybean defense genes by the phosphoprotein phosphatase inhibitor okadaïc acid. Plant Sci. 109:165-170.

Hammond-Kosack, K. E., and Jones, J. D. G. 1996. Resistance genedependent plant defense responses. Plant Cell 8:1773-1791.

Hammond-Kosack, K. E., and Jones, J. D. G. 1997. Plant disease resistance genes. Annu. Rev. Plant Physiol. Plant Mol. Biol. 48:575-607.

He, D.-Y., Yazaki, Y., Nishizawa, Y., Takai, R., Yamada, K., Sakano, K., Shibuya, N., and Minami, E. 1998. Gene activation by cytoplasmic acidification in suspension-cultured rice cells in response to the potent elicitor, $N$-acetylchitoheptaose. Mol. Plant-Microbe Interact. 11:11671174.

Jonak, C., Ligterink, W., and Hirt, H. 1999. MAP kinases in plant signal transduction. Cell Mol. Life Sci. 55:204-213.

Keen, N. T. 1992. The molecular biology of disease resistance. Plant Mol. Biol. 19:109-122.
Laemmli, U. K. 1970. Cleavage of structural proteins during the assembly of the head of bacteriophage T4. Nature 227:680-685.

Lamb, C., and Dixon, R. A. 1997. The oxidative burst in plant disease resistance. Annu. Rev. Plant Physiol. Plant Mol. Biol. 48:251-275.

Lebrun-Garcia, A., Ouaked, F., Chiltz, A., and Pugin, A. 1998. Activation of MAPK homologues by elicitors in tobacco cells. Plant J. 15:773-781.

Leung, J., Bouvier-Durand, M., Morris, P.-C., Guerrier, D., Chefdor, F., and Giraudat, J. 1994. Arabidopsis ABA response gene ABI1: Features of a calcium-modulated protein phosphatase. Science 264:1448-1452.

Levine, A., Tenhaken, R., Dixon, R., and Lamb, C. 1994. $\mathrm{H}_{2} \mathrm{O}_{2}$ from the oxidative burst orchestrates the plant hypersensitive disease resistance response. Cell 79:583-593.

Martin, G. B., Brommonschenjel, S. H., Chunwongse, J., Earle, E. D., and Tannksley, S. D. 1993. A member of tomato Pto gene family confers sensitivity to fenthion resulting in rapid cell death. Plant Cell 6:1543-1552.

Mathieu, Y., Sanchez, F. J., Droillard, M.-J., Lapous, D., Laurière, C., and Guern, J. 1996. Involvement of protein phosphorylation in the early steps of transduction of the oligogalacturonide signal in tobacco cells. Plant Physiol. Biochem. 34:399-408.

Mehdy, M. C. 1994. Active oxygen species in plant defense against pathogens. Plant Physiol. 105:467-472.

Meyer, K., Leube, M. P., and Grill, E. 1994. A protein phosphatase 2C involved in ABA signal transduction in Arabidopsis thaliana. Science 264:1452-1455.

Pugin, A., Frachisse, J. M., Tavernier, E., Bligny, R., Gout, E., Douce, R., and Guern, J. 1997. Early events induced by the elicitor cryptogein in tobacco cells: involvement of a plasma membrane NADPH oxidase and activation of glycolysis and the pentose phosphate pathway. Plant Cell 9:2077-2091.

Ramagali, L. S., and Rodrigues, L. V. 1985. Quantification of microgram amounts of protein in two-dimensional polyacrylamide gel electrophoresis sample buffer. Electrophoresis 6:559-563.

Reymond, P., Grünberger, S., Paul, K., Müller, M., and Farmer, E. E. 1995. Oligogalacturonide defense signals in plants: large fragments interact with the plasma membrane in vitro. Proc. Natl. Acad. Sci. USA 92:4145-4149.

Ricci, P. 1997. Induction of the hypersensitive response and systemic acquired resistance by fungal proteins: the case of elicitins. Pages 5375 in: Plant-Microbe Interactions. G. Stacey and N. T. Keen, eds. Chapman and Hall, New York.

Salzer, P., Hebe, G., Reith, A., Zitterell-Haid, B., Stransky, H., Gaschler, K., and Hager, A. 1996. Rapid reactions of spruce cells to elicitors released from the ectomycorrhizal fungus Hebeloma crustiliniforme, and inactivation of these elicitors by extracellular spruce cell enzymes. Planta 198:118-126.

Smith, R. D., and Walker, J. C. 1996. Plant protein phosphatases. Annu. Rev. Plant Physiol. Plant Mol. Biol. 47:101-125.

Song, W. Y., Wang, G. L., Chen, L. L., Kim, H. S., Pi, L. Y., Gardner, J., Wang, B., Holsten, T., Zhai, W. X., Zhu, L. H., Fuauquet, C., and Ronald, P. C. 1995. A receptor kinase-like protein encoded by the rice disease resistance gene Xa21. Science 270:1804-1806.

Sopory, S. K., and Munshi, M. 1998. Protein kinases and phosphatases and their role in cellular signaling in plants. Crit. Rev. Plant Sci. 17: 245-318.

Stone, J. M., Collinge, M. A., Smith, R. D., Horn, M. A., and Walker, J. C. 1994. Interaction of a protein phosphatase with an Arabidopsis serine-threonine receptor kinase. Science 266:793-795.

Stone, J. M., Trotochaud, A. E., Walker, J. C., and Clark, S. E. 1998. Control of meristem development by CLAVATA1 receptor kinase and kinase-associated protein phosphatase interactions. Plant Physiol. 117:1217-1225.

Stone, J. M., and Walker, J. C. 1995. Plant protein kinase families and signal transduction. Plant Physiol. 108:451-457.

Subramaniam, R., Desprès, C., and Brisson, N. 1997. A functional homolog of mammalian protein kinase $\mathrm{C}$ participates in the elicitorinduced defense response in potato. Plant Cell 9:653-664.

Sutherland, M. W. 1991. The generation of oxygen radicals during host plant responses to infection. Physiol. Mol. Plant Pathol. 39:79-93.

Tavernier, E., Wendehenne, D., Blein, J. P., and Pugin, A. 1995. Involvement of free calcium in action of cryptogein, a proteinaceous elicitor of hypersensitive reaction in tobacco cells. Plant Physiol. 109: 1025-1031. 
Trotochaud, A. E., Hao, T., Wu, G., Yang, Z., and Clark, S. E. 1999. The CLAVATA1 receptor-like kinase requires CLAVATA3 for its assembly into a signaling complex that includes KAPP and a Rho-related protein. Plant Cell 11:393-405.

Viard, M. P., Martin, F., Pugin, A., Ricci, P., and Blein, J. P. 1994. Protein phosphorylation is induced in tobacco cells by the elicitor cryptogein. Plant Physiol. 104:1245-1249.

Williams, R. W., Wilson, J. M., and Meyerowitz, E. M. 1997. A possible role for kinase-associated protein phosphatase in the Arabidopsis CLAVATA1 signaling pathway. Proc. Natl. Acad. Sci. USA 94:1046710472 .

Wendehenne, D., Binet, M. N., Blein, J. P., Ricci, P., and Pugin, A. 1995. Evidence for specific high-affinity binding sites for a proteina- ceous elicitor in tobacco plasma membrane. FEBS Lett. 374:203-207. Xing, T., Higgins, V. J., and Blumwald, E. 1997. Race-specific elicitors of Cladosporium fulvum promote translocation of cytosolic components of NADPH oxidase to the plasma membrane of tomato cells. Plant Cell 9:249-259.

Yang, Y., Shah, J., and Klessig, D. F. 1997. Signal perception and transduction in plant defense responses. Genes Dev. 11:1621-1639.

Yu, L. M. 1995. Elicitins from Phytophthora and basic resistance in tobacco. Proc. Natl. Acad. Sci. USA 92:4088-4094.

Zhang, S., Du, H., and Klessig, D. F. 1998. Activation of the tobacco SIP kinase by both a cell wall-derived carbohydrate elicitor and purified proteinaceous elicitins from Phytophthora spp. Plant Cell 10: 435-449. 